\title{
Language Learning Strategies: A Comparative Study of Young and Adolescent Cambodian Learners
}

\author{
Davut Nhem \\ Norton University, Cambodia \\ davut_nhem124@yahoo.com
}

$\begin{array}{ll}\text { Received: } & \text { Abstract } \\ 20 / 07 / 2019 & \text { Various aspects of second language learning such as motivation, social } \\ & \text { contexts, personality, learning styles or learning strategies should be taken } \\ \text { Accepted: } & \text { into consideration when it comes to teaching and learning a new language. in } \\ 28 / 08 / 2019 & \text { this respect, one of the most overlooked factors is a language learning } \\ & \text { strategy. Language learners should be aware of "how to learn a language" to } \\ & \text { be a successful language learner. As language learning strategy has been } \\ \text { Keywords: } & \text { recognized as the important factor in learning a second language (O'Malley \& } \\ \text { Language Learning } & \text { Chamot, 1990; and Oxford, 1990), this study therefore investigated language } \\ \text { Strategies, } & \text { learning strategies employed by young and adolescent learners of English in } \\ \text { Metacognitive } & \text { Cambodia context. The data were collected through a questionnaire, } \\ \text { Strategies, } & \text { developed by Oxford (1990) from 152 students. The findings showed that } \\ \text { Compensation } & \text { students mostly used cognitive, metacognitive and social strategies. In } \\ \text { Strategies } & \text { addition, when examining if young learners use different learning strategies } \\ & \text { from adolescent learners, no statistical difference was found, except for two } \\ & \text { learning strategies, namely, cognitive and compensation strategies used more } \\ & \text { frequently by young learners. }\end{array}$

1. INTRODUCTION

Using different language learning strategies would lead to different results of L2 learning. Oxford (1990) claims that the effectiveness of language learning requires effective learning strategies. In this regard, Ortega (2013) asserts that learning strategies refer to the conscious mental and behavioral processes allowing learners to take part in monitoring their own learning progress. Rubin (1975; cited in Ortega, 2013) summarizes the behavioral characteristics of a good language learner into six major attributes: good use of guessing skills, focusing on form-and-meaning, trying out new knowledge, monitoring the learning process themselves and that of others, regularly practice the new language, and being to handle their emotions.

The term language learning strategy has been defined differently. Wenden and Rubin (1987; cited in Pineda, 2010) define learning strategies as any groups of operations, steps, plans, routines or behaviors used by the learners to facilitate the process of obtaining, storage, retrieval, and implication of information. Similarly, O'Malley and Chamot (1990) view "learning strategies as the special thoughts or behaviors that individuals use to help them comprehend, learn, or retain new information" (p. 1). Oxford (1990) defines that "learning strategies are specific actions taken by the learners to make learning easier, faster, more enjoyable, more self-directed, more effective and more transferable to new information" ( $p$. 8). Moreover, learning strategies can be referred to any learning activities which students perform to obtain new language information (Al-Qirim et al., 2014). Language learning strategies can also refer to the behaviors and techniques that students use to learn a new language (Saville-Troike, 2012). As can be seen, the definitions of language learning strategies have been rooted or centered on the tools and facilitation of language learners to acquire new language inputs effectively. 
As language learning strategy has been regarded as one the most crucial factors in second language education (Ortega, 2013; Saville-Troike, 2012; O'Malley \& Chamot, 1990; Oxford, 1990), the issue of using language learning strategies remains overlooked by teachers and learners of language in ELT classrooms, especially in Cambodia context. In Cambodia, previous studies have focused on different aspects such as standardized test in language teaching (Kea et al., 2015), teacher research (Keuk, 2015), social awareness (Chan, 2014), and writing feedback (Sou, 2013). However, research on language learners' strategies has gone untouched by the previous studies. Therefore, this paper presents a study which examined language learning strategies used by two different age groups (young learners: 1013 and adolescent learners: 14-19) of language learners at one school in Phnom Penh. Therefore, the study was guided by the following questions:

a) What language learning strategies do Cambodian learners use the most?

b) To what extent is there any difference between young and adolescent learners in using language learning strategies?

\section{LITERATURE REVIEW}

Although many language learning strategies have been identified, the effectiveness of each learning strategy is mainly based on specific learning contexts, learners, and learners' learning styles (Saville-Troike, 2012). O'Malley and Chamot (1987; cited in Saville-Troike, 2012) form a typology of language-learning strategies which include: metacognitive, cognitive, and social/affective (See F.1). The three groups of learning strategies have been introduced widely in SLA.

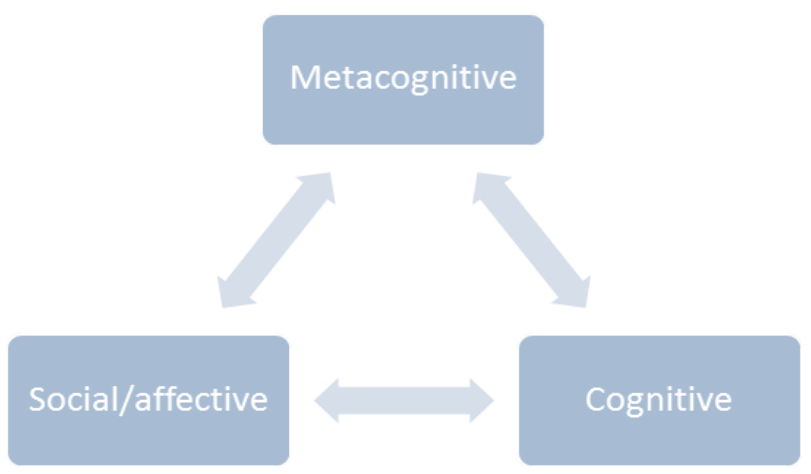

\section{Figure 1. Language Learning Strategies}

- Metacognitive Strategy: Language learners who employ this strategy usually take control of their learning progress by planning and monitoring themselves. In other words, students prefer anticipating learning activities and preparing themselves in advance about which learning tasks that they should get involved. The drill of linguistics features is frequently practiced before commence of the lesson.

- Cognitive Strategy: Students usually analyze or synthesis of linguistic components (e.g. structures, forms, words, or phrases) or repeat a language model after it has been introduced. Learners try to remember a new word by relating the sound to the one in L1. They can also practice making a vivid image to represent a new word.

- Social/Affective: In this strategy, learners usually work with other peers when learning new words or linguistic features. They like discussing, asking for clarification, examples, giving or getting feedback from other learners or teacher on the purpose of improving their learning outcome. 
Later on, Oxford (1990) categorizes LLs into two groups: direct strategies, referring to the activities influencing directly the learning process, and indirect strategies referring to activities which have an indirect influence on the learning process. These two groups of learning strategies mutually underpin each other well (Oxford, 1990). In this sense, it means that direct strategies work with new language input through diversifications of learning tasks and conditions. This is due to the fact that direct learning strategy group includes: (1) memory strategies dealing with recalling, or storing new language information; (2) cognitive strategies for comprehending and creating the language; and (3) compensation strategies which are used for dealing with the language in spite of the knowledge gaps. On the other hand, indirect strategies composed of (1) metacognitive strategies which coordinate language learning process; (2) affective strategies which are used for controlling emotions of learners; and (3) social strategies which learners use to work with others (Oxford, 1990).



Figure 2. Inter-relationships between direct and indirect strategies among the six strategy groups (Oxford 1990: p. 15)

Rubin (1994; in Pineda, 2010) forms LLs into three groups: learning strategies, communication strategies, and social strategies. Learning strategies have a direct impact on students' learning process while communication strategies are mainly used in the performance of language. Social strategies allow learners to engage in interaction with others when learning the language. However, it could be stated that the learning strategy system, developed by Oxford (1990) provides comprehensive and detailed information related to the four language skills such as reading, listening, speaking and writing (Oxford, 1990). Thus, this study adopted Oxford's (1990) strategies for the sake of determining the use of language learning strategies by two groups of learners (young and adolescent learners).

\subsection{Previous Studies on Language Learning Strategies}

In recent time, various studies (e.g. Aljuaid, 2010; Chilkiewicz, 2015; Fazle \& Khan, 2012; Kaur \& Embi, 2011; \& Pineda, 2010) have investigated teachers' and learners' perception of the use of language learning strategies. However, none of these studies had compared the language learning strategies used by young learners and adolescent learners. Those studies have, therefore, shed light for this study to further investigate the learning strategies used by young and adolescent learners of English and make a comparison of their learning strategies. 
One study (Chilkiewicz, 2015) traced language learning strategies mainly used by a group of students (11-12 years old). One hundred students in grade 5th and 6th from a primary school in Maszewo responded to the questionnaire, adapted from Oxford (1990). The questionnaire includes six sub-groups of language learning strategies (memory, cognitive, compensation, metacognitive, affective, and social strategies). The results indicated that most students preferred memory strategy for recalling and storing new language. The study also indicated that cognitive strategy was perceived as the common use of learning strategy by the students. The result of memory strategy was inconsistent with the study by Fazle and Khan (2012), which explored the relationship between teachers' and students' perception of language learning strategies. One hundred and twenty students who were studying English in different universities in Bangladesh and in the Kingdom of Saudi Arabia answered the questionnaire, adapted from Oxford (1990). The findings revealed a remarkable difference between teachers' belief and learners' practice. The students mostly used social strategy, metacognitive strategy, cognitive, and compensation while the teachers thought that students used more memory strategy, cognitive strategy, and compensation strategy. Those teachers did not think that social and affective strategies were not mainly used by the students. However, it could be noticed that cognitive strategy was found to be positive in both studies (Fazle \& Khan, 2012; Fazle \& Khan, 2012).

Aljuaid's (2010) study examined the frequent use of language learning strategies by a group of female students who were studying English major at Saudi Arabian University. One hundred and eleven female students responded to the questionnaire, adapted from Oxford's (1990) language learning strategy inventory. The results indicated that students frequently used metacognitive, social, affective and cognitive strategies. Memory strategy and compensation strategy were not seen positive results by the study. These results cooperated with the study by Fazle \& Khan (2012) and the study by Chilkiewicz (2015) on cognitive strategy. Drawn from the review of these studies (Aljuaid, 2010; Fazle \& Khan, 2012; Fazle \& Khan, 2012), it could be assumed that cognitive strategy has been preferred by different groups of learners (e.g. young learners, adult learners, male and female students). However, social strategy and metacognitive strategy have been favored more by adult learners.

While the above studies traced different learning strategies from young learners (Chilkiewicz, 2015), teachers' and learners' perception (Fazle \& Khan, 2012), and female adult learners (Aljuaid, 2010), two other studies (Kaur \& Embi, 2011; Tam, 2013) have compared the use of language learning strategies by different genders. Kaur and Embi (2011) made a comparison on language learning strategies used by male and female students in a primary school. The questionnaire adapted from Oxford and Chi (2002) was given to 60 students (30 males and 30 females) from two classes to complete. The results revealed that female students used more strategies than those male students, especially on listening, speaking and reading strategies while there was no significant difference in writing strategy. These results were also supported by Tam's (2013) study which investigated the relationship of genders, second language proficiency, and socioeconomic status on language learning strategies. Fifty undergraduate students (first-year students) at the Hong Kong Polytechnic University responded to the questionnaire, adapted from (Oxford, 1990). The results showed that female students frequently used more learning strategies than male students (e.g. memory, compensation, cognitive, metacognitive, and social strategies). The use of compensation, cognitive, and social strategies by the students were shown a positive relationship with language proficiency while socioeconomic status had a significant impact on students' use of social strategies. In addition, the relationship between language learning strategies and learning achievement was found positive by a study (Abdul-Ghafour \& 
Alrefaee, 2019). The results of the study indicated that high achievement students employed language learning strategies such as meta-cognitive, compensation and cognitive strategies while low achievement students preferred to use meta-cognitive strategies and affective strategies.

\section{METHOD}

Quantitative research, following Creswell (2014), was employed in the study to describe and determine the relationship of variables in large samples. It also provides the explanation of the degree of relationship of variables (Fraenkel, et al., 2012). In regard to this, the study aimed to explore language learning strategies used by young learners and adolescent learners of English language in a general English program in one school in Phnom Penh, Cambodia. The school provides the Khmer Educational Program from kindergarten to grade 12, Chinese Program, and English Programs including Young Learner Program (YLP) and Adult English Program (AEP). The Adult English Program is divided into two: Intensive English Program (IEP) and Part-time English Program (PEP). In these programs, students were taught by the course instructors who were both native and non-native speakers of English. In addition, convenience sampling was utilized in the study because it allowed accessing students who were available for the study (Fraenkel, et al., 2012). One hundred and fifty-two students $(\mathrm{N}=73$ young learners; $\mathrm{N}=79$ adolescent learners) answered the questionnaire, adapted from Oxford (1990). The questionnaire consists of 50 items representing six learning strategies include memory, cognitive, metacognitive, compensation, affective and social strategies.

The data was entered and analyzed in SPSS version 23 and reported in mean, standard deviation, and p-value. All the items were combined into six categories which include: memory strategy (items 1-9), cognitive strategy (items 10-23), compensation strategy (items 24-29), metacognitive strategy (items 30-38), affective strategy (items 39-44), and social strategy (items 45-50). The statements were rated by a five-point Likert scale ( $1=$ Never to $5=$ Always). Descriptive statistics were used to analyze frequency data; the mean scores of the students were used to compare with the average mean score of each learning strategy category. Moreover, independent samples t-test was used to analyze the differences of learning strategies used by the students.

\section{RESULTS}

\subsection{Language Learning Strategies of Young and Adolescent Learners}

Table 1 shows the mean scores of the use of language learning strategies of a group of EFL Cambodian students in one school. The results revealed that cognitive strategy $(M=46)$ and metacognitive strategy $(M=31)$ were used frequently by these students. It could mean that the students are likely to use different ways to acquire the English language (e.g. practicing speaking English with others, writing letters or messages in English, reading English books, listening to English music or watching English movies) (cognitive strategies). In metacognitive strategy, students attempt to look for opportunities for practicing English with other students or teachers. They make plan or schedule for learning and monitor their own learning progress. Students are willing to make mistakes and learning from the mistakes. In addition to cognitive and metacognitive strategies, social strategy was also shown to be frequently used by the students $(\mathrm{M}=20)$. This means that the students prefer using English as a means for communicative purposes. In the classroom, they usually have conversations in English. In addition, these students prefer learning the culture of English speakers. 
Table 1. Student Learning Strategies ((Mean Score ( $N=152$ students))

\begin{tabular}{lcc}
\hline Variables & Score Range & M \\
\hline Memory Strategy & $9-45$ & 26 \\
\hline Cognitive Strategy & $14-70$ & 46 \\
\hline Compensation Strategy & $6-30$ & 18 \\
\hline Metacognitive Strategy & $9-45$ & 31 \\
\hline Affective Strategy & $6-30$ & 18 \\
\hline Social Strategy & $6-30$ & 20
\end{tabular}

However, the results did not show much positive toward other learning strategies (memory, compensation, and affective). For example, the mean score of memory strategy is 26 out of 45 . This could be inferred that the students were not likely to memorize new words or reviewing the lesson often. The results also indicated that compensation strategy was not received much attention from the students $(M=18)$. This could mean that learners were not likely to try to figure out different ways to communicate in English when they are lack of linguistic resources to convey ideas. For instance, they might not want to make gestures or use a word or phrase that has a similar meaning to what they want to say. Last but not least, the study also did not reveal positive results toward the use of affective strategy by these students $(M=18)$. It could be noticed that students who use affective strategy, they tend to look for relaxing moments so that they can speak English. They need encouragement from themselves in order to speak English.

\subsection{Comparison of Language Learning Strategies of Young and Adolescent Learners}

Table 2 shows the results of the comparison of young learners and adolescent learners in the use of the six sub-groups of language learning strategies. The results revealed that the two groups of students did differ in the use of cognitive strategy $(\mathrm{p}=.033)$. The mean score of young learners (47.60) is statistically different from the adolescent learners (44.94). This means that young learners used cognitive strategy more than adolescent learners did. In addition, there was a significant difference between the two groups in the use of compensation strategy $(\mathrm{p} \leq 050)$. The mean score of young learners is 18.75 and the mean of adolescent learners is 17.46. However, there was no statistic difference in the other four groups of language learning strategies (memory strategy, $\mathrm{p}=.137$; metacognitive strategy, $\mathrm{p}=.150$; affective strategy, $\mathrm{p}=.595$, and social strategy, $\mathrm{p}=.287$ ). Therefore, it could be concluded that young learners and adolescent learners did not use these language learning strategies differently. 
Table 2. Comparison of LLSs of Young and Adolescent Learners ( $N=73$ young learners; $N=79$ adolescent learners)

\begin{tabular}{cccccc}
\hline Variables & $\boldsymbol{M}$ & $\boldsymbol{S D}$ & $\boldsymbol{t}$ & $\boldsymbol{d f}$ & $\boldsymbol{p}$ \\
\hline $\begin{array}{c}\text { Memory Strategy } \\
\quad \text { Young Learners }\end{array}$ & 26.77 & 4.88 & 1.50 & 150 & .137 \\
Adolescent Learners & 25.51 & 5.47 & & & \\
\hline $\begin{array}{c}\text { Cognitive Strategy } \\
\quad \text { Young Learners }\end{array}$ & 47.60 & 7.77 & 2.15 & 150 & .033 \\
$\quad$ Adolescent Learners & 44.94 & 7.48 & & & \\
\hline $\begin{array}{c}\text { Compensation Strategy } \\
\quad \text { Young Learners }\end{array}$ & 18.75 & 4.47 & 1.98 & 137 & .050 \\
$\quad$ Adolescent Learners & 17.46 & 3.55 & & & \\
\hline $\begin{array}{c}\text { Metacognitive Strategy } \\
\quad \text { Young Learners }\end{array}$ & 32.10 & 6.31 & 1.46 & 150 & .147 \\
$\quad$ Adolescent Learners & 30.71 & 5.42 & & & \\
$\quad$ Affective Strategy & & & & & \\
$\quad$ Young Learners & 18.25 & 4.38 & .53 & 150 & .595 \\
Adolescent Learners & 17.87 & 4.25 & & & \\
$\quad \quad$ Social Strategy & & & & & \\
$\quad$ Young Learners & 21.16 & 4.61 & 1.07 & 150 & .287 \\
Adolescent Learners & 20.35 & 4.72 & & & \\
\hline
\end{tabular}

\section{DISCUSSION}

With regard to the first research question, the results revealed that EFL Cambodian students in this study preferred using cognitive, metacognitive, and social strategies more than the other strategies (e.g. memory, compensation, and affective). This could be informed that the students actively involved in learning the English language through different ways (e.g. practicing listening to English music, watching English movies, monitoring their learning, or seeking opportunities to communicate with others in English). The results of this study support the studies (Aljuaid, 2010; Fazle \& Khan, 2012 \& Khaleel Mohammad Abdul-Ghafar \& Alrefaee, 2019) which revealed that social strategy, metacognitive strategy, and cognitive strategy had been highly favored by EFL students in the context of Bangladesh (Fazle \& Khan, 2012) and the Kingdom of Saudi Arabia (Aljuaid, 2010; \& Fazle \& Khan, 2012). In addition, this study further concurs with Chilkiewicz's (2015) study, which investigated 11-12 years-old learners of English in Maszewo, on the result of the cognitive strategy. Therefore, it could be concluded that cognitive, metacognitive, and social strategies have been highly preferred by different groups of students in diverse educational settings when it comes to learning the English language.

The second research question examined whether or not the young learners and adolescent learners differ in their use of language learning strategies. The results indicated that two categories of learning strategy, namely cognitive strategy and compensation strategy were found to be statistically different. For instance, the mean of young learners who preferred using cognitive strategy $(M=47.60)$ is significantly different from adolescent learners $(\mathrm{M}=44.94)$ and $\mathrm{p}=.033$. This means that young learners used more cognitive strategy than adolescent learners. This result concurs with the study by Chilkiewicz (2015) which explored young learners' (11-12 years-old) preference for using language learning strategies in Maszewo. This could be concluded that young learners prefer learning language by getting exposure to the target language in different means (e.g. saying or writing English several 
times, reading for pleasure in English, or trying to understand the meaning in English). Moreover, young learners also used compensation strategy more than adolescent learners $(\mathrm{M}=18.75$ for young learners; $\mathrm{M}=17.46$ for adolescent learners $)$ and $\mathrm{p} \leq 050$. This result seeks to support the studies by Fazle \& Khan (2012) and Kaur \& Embi (2011). Fazle's \& Khan's (2012) study reported that EFL university students in Bangladesh and the Kingdom of Saudi Arabia preferred using compensation strategy when they learned English. For example, they might make gestures when they do not understand unfamiliar English words during conversation. The study by Kaur \& Embi (2011) also revealed that female students (year-one students) at the Hong Kong Polytechnic University preferred using compensation strategy in learning English. Therefore, it could be inferred that older learners seem to seek ways to communicate or express ideas when they face a challenge of linguistic knowledge.

The implications of the data analysis could not be extrapolated in large samples. More empirical studies on the topic should be conducted in various educational settings. However, this study provides educators with some insights regarding students' preference for using language learning strategies in Cambodia context. Furthermore, as it has been widely known that language learning strategies are of importance for all learners in various educational contexts and backgrounds, some of these learning strategies have been neglected by the learners. In this manner, it could be recommended that language teachers should inform or teach students regarding the different language learning strategies to students and explain the significance of each language learning strategy to students so that they can have some ideas about which learning strategy is more relevant to them, and when or why they should use the learning strategies. Chamot $(1998$, p. 6) provides some guidelines for teaching language learning strategies: (1) building on the learning strategies which students already use, (2) integrating learning strategy in regular lessons, (3) explaining students explicitly with reasons, procedures, and when to use each strategy, (4) providing students with choices of choosing learning strategies, (5) planning the integration of learning strategy throughout the course, and (6) using the target language as much as you can when teaching learning strategies to students. In addition, he also developed an instructional framework for teaching language learning strategies to EFL students. The following is a summary of the methodological framework of learning strategy instruction which is divided into seven steps (Chamot, 1998, p. 7):

1. Preparation: Teacher asks students to make a list of learning strategies that they already use.

2. Presentation 1: Teacher introduces the new learning strategy to the class.

3. Practice 1: Students practice the learning strategy which they have learned. For instance, students are required to read a text in English.

4. Presentation 2: Teacher provides a model and discussion of second learning strategy that could work best for students.

5. Practice 2: Students practice the second learning strategy.

6. Evaluation: Teacher asks students to reflect on each learning strategy and provide some reasons of the challenges as well as their improvements.

7. Expansion: Teacher can assign homework to students and asks students to use the learning strategies that they have learned in the class. Students will have to report their experience to the class.

\section{CONCLUSION}

Although the present study indicated the fruitful results of the language learning strategies used by young learners and adolescent learners, it failed to understand the factors that influence the use of language learning strategies by students. The further study should 
focus on those factors to better understand the language learning strategies used by students in Cambodia context and beyond. This study investigated the practice of language learning strategies by learners in private schools in Phnom Penh, Cambodia. The results indicated that three language learning strategies, that is to say, cognitive, metacognitive, and social strategies were mainly used by the students. In addition, two learning strategies were found to be statistically different in relation to the use of language learning strategies by the two groups of students, namely young learners and adolescent learners. The findings indicate that young learners tend to use more language learning strategies than most adolescent learners for two strategies, namely cognitive strategy and compensation strategy. These results provide fruitful information for teachers and school leaders to provide training in relation to language learning strategies, which students have not mostly applied in their learning, to learners to develop their learning skills. It could be possible that most language teachers are skeptical about why some learners perform better than others, no matter how much the teacher tries to help them learn the language. The differences of ability, motivation, and effort may be some parts contributing to the success of language learning, but the most crucial one is the scholarship of "how to learn" a language or called "language learning strategies" (Chamot, 1998). As discussed above, to be a successful language learner, students should be aware of and employ a variety of language learning strategies to develop their learning skills, especially communicative competence. Language teachers should provide their students with language learning strategies to help them process the language effectively.

\section{REFERENCES}

Abdul-Ghafour, A. K., \& Alrefaee, Y. (2019). The relationship between language earning strategies and achievement among EFL university students. Applied Linguistics Research Journal, 3(3), 64-83.

Aljuaid, H. (2010). Language learning strategies: perceptions of female Saudi EFL learners. Lancaster University Postgraduate Conference in Linguistics \& Language Teaching 2010, (pp. 2-24).

Al-Qirim, N., Khalil, A., Yammahi, A., \& Yammahi, M. (2014). Student learning strategies: a conceptual framework. Advanced Science and Technology Letters, 47, 270-276. Retrieved from: http://onlinepresent.org/proceedings/vol47 2014/62.pdf

Chamot, A. U. (1998). Teaching learning strategies to language students. Educational Resources Information Center (ERIC), 1-25.

Chan, V. (2014). Integrating social awareness through reading and writing: A classroom action research. Language Education in Asia, 5(2), 216-227.

Chilkiewicz, K. (2015). Direct language learning strategies in the theory by Rebecca Oxford in English vocabulary acquisition at the age group of 11-12 year olds. World Scientific News, 7, 179-206.

Creswell, J. W. (2014). Research desgin: qualitative, quantitative, and mixed methods approaches (4 ed.). California: SAGE Publications, Inc.

Fazle, M., \& Khan, R. (2012). Language learning strategies: a study of teacher and learner perceptions. BUP JOURNAL, 1(1), 140-153.

Fraenkel, J. R., Wallen, N. E., \& Hyun, H. H. (2012). How to Design and evaluate research in education (8 ed.). New York: McGraw-Hill.

Kaur, M., \& Embi, M. (2011, October). The Relationship between language learning strategies and gender among primary school students. Theory and Practice in Language Studies, 1(10), 14321436. doi:10.4304/tpls.1.10.1432-1436 
Kea, L., Meng, C., \& Keuk, C. N. (2015). Cambodian ELT university practitioners' use of standardized tests for practice and assessment. Language Education in Asia, 6(1), 4-16.

Keuk, C. N. (2015). Participation in teacher research at a tertiary institution in Cambodia. Language Education in Asia, 6(1), 31-45.

O'Malley, J. M., \& Chamot, A. (1990). Learning strategies in second language acquisition. New York: Cambridge Univesity Press.

Ortega, L. (2009). Understanding second language acquisition. London \& New York: Routledge.

Ortega, L. (2013). Understanding second language acquisition. New York: Routledge.

Oxford, R. L. (1990). Language learning strategies: what every teacher should know. New York: Newbury House.

Pineda, J. E. (2010). Identifying language learning strategies: an exploratory study. Gist Education and Learning Research Journal, 4(1), 94-106.

Saville-Troike, M. (2012). Introducing Second Language Acquisition. United Kingdom: Cambridge University Press.

Sou, B. (2013). Using directive and facilitative feedback to improve student writing: A case study of a higher education setting in Cambodia. Language Education in Asia, 140-174.

Tam, C.-H. K. (2013). A study on language learning strategies (LLs) university students in Hong Kong. Taiwan Journal of Linguistics, 11(2), 1-42. 


\section{APPENDIX}

\section{QUESTIONNAIRE}

- Please fill in the following questions about your personal information. Please check $(\mathrm{V})$ your answer in the appropriate box.

\section{Personal Data}
1. Sex: $\square$ Male
$\square$ Female
2. Age:
3. Level:
4. Program: $\square$ IEP
$\square$ PEP
$\square$ YLP
5. Shift: $\square$ Morning
$\square$ Afternoon
$\square$ Evening

6. School:

- Please answer the following questions about your personal experiences in learning English. Please circle your answer in the appropriate column $(1,2,3,4$, or 5$)$.

Note:

I. Never or almost never true of $m e=0-10 \%$

2. Usually not true of $m e=20-30 \%$

3. Somewhat true of $m e=40-60 \%$

4. Usually true of me $=70-80 \%$

5. Always or almost always true of $m e=90-100 \%$

\section{Description}

\section{Part A: Memory}

1. I think of relationships between what I already know and new things I learn in English.

2. I use new English words in a sentence so I can remember them.

3. I connect the sound of a new English word and an image or picture of the word to help remember the word.

4. I remember a new English word by making a mental picture of a situation in which the word might be used.

5. I use rhymes to remember new English words.

6. I use flashcards to remember new English words.

7. I physically act out new English words.

8. I review English lessons often.

9. I remember new English words or phrases by remembering their location on the page, on the board, or on a street sign.

\section{Part B: Cognitive}

10. I say or write new English words several times.

11. I try to talk like native English speakers.

12. I practice the sounds of English.

13. I use the English words I know in different ways.

14. I start conversations in English.

15. I watch English language TV shows spoken in English or go to movies spoken in English

16. I read for pleasure in English.

17. I write notes, messages, letters, or reports in English.

18. I first skim an English passage (read over the passage quickly) then go back and read carefully.

19. I look for words in my own language that are similar to new words in 


\begin{tabular}{|c|c|c|c|c|c|}
\hline English. & & & & & \\
\hline 20. I try to find patterns in English. & 1 & 2 & 3 & 4 & 5 \\
\hline $\begin{array}{l}\text { 21. I find the meaning of an English word by dividing it into parts that I } \\
\text { understand. }\end{array}$ & 1 & 2 & 3 & 4 & 5 \\
\hline 22. I try not to translate word-for-word. & 1 & 2 & 3 & 4 & 5 \\
\hline 23. I make summaries of information that I hear or read in English. & 1 & 2 & 3 & 4 & 5 \\
\hline Part C: Compensation & & & & & \\
\hline 24. To understand unfamiliar English words, I make guesses. & 1 & 2 & 3 & 4 & 5 \\
\hline 25. When I can't think of a word during a conversation in English, I use gestures. & 1 & 2 & 3 & 4 & 5 \\
\hline 26. I make up new words if I do not know the right ones in English. & 1 & 2 & 3 & 4 & 5 \\
\hline 27. I read English without looking up every new word. & 1 & 2 & 3 & 4 & 5 \\
\hline 28. I try to guess what the other person will say next in English. & 1 & 2 & 3 & 4 & 5 \\
\hline $\begin{array}{l}\text { 29. If I can' } t \text { think of an English word, I use a word or phrase that means the } \\
\text { same thing }\end{array}$ & 1 & 2 & 3 & 4 & 5 \\
\hline Part D: Metacognitive & & & & & \\
\hline 30. I try to find as many ways as I can to use my English. & 1 & 2 & 3 & 4 & 5 \\
\hline 31. I notice my English mistakes and use that information to help me do better. & 1 & 2 & 3 & 4 & 5 \\
\hline 32. I pay attention when someone is speaking English. & 1 & 2 & 3 & 4 & 5 \\
\hline 33. I try to find out how to be a better learner of English. & 1 & 2 & 3 & 4 & 5 \\
\hline 34. I plan my schedule so I will have enough time to study English. & 1 & 2 & 3 & 4 & 5 \\
\hline 35. I look for people I can talk to in English. & 1 & 2 & 3 & 4 & 5 \\
\hline 36. I look for opportunities to read as much as possible in English. & 1 & 2 & 3 & 4 & 5 \\
\hline 37. I have clear goals for improving my English skills. & 1 & 2 & 3 & 4 & 5 \\
\hline 38. I think about my progress in learning English. & 1 & 2 & 3 & 4 & 5 \\
\hline Part E: Affective & & & & & \\
\hline 39. I try to relax whenever I feel afraid of using English. & 1 & 2 & 3 & 4 & 5 \\
\hline $\begin{array}{l}\text { 40. I encourage myself to speak English even when I am afraid of making a } \\
\text { mistake. }\end{array}$ & 1 & 2 & 3 & 4 & 5 \\
\hline 4I. I give myself a reward or treat when I do well in English. & 1 & 2 & 3 & 4 & 5 \\
\hline 42. I notice if I am tense or nervous when I am studying or using English. & 1 & 2 & 3 & 4 & 5 \\
\hline 43. I write down my feelings in a language learning diary. & 1 & 2 & 3 & 4 & 5 \\
\hline 44. I talk to someone else about how I feel when I am learning English. & 1 & 2 & 3 & 4 & 5 \\
\hline Part F: Social & & & & & \\
\hline $\begin{array}{l}\text { 45. If I do not understand something in English, I ask the other person to slow } \\
\text { down or say it again. }\end{array}$ & 1 & 2 & 3 & 4 & 5 \\
\hline 46. I ask English speakers to correct me when I talk. & 1 & 2 & 3 & 4 & 5 \\
\hline 47. I practice English with other students. & 1 & 2 & 3 & 4 & 5 \\
\hline 48. I ask for help from English speakers. & 1 & 2 & 3 & 4 & 5 \\
\hline 49. I ask questions in English. & 1 & 2 & 3 & 4 & 5 \\
\hline 50. I try to learn about the culture of English speakers. & 1 & 2 & 3 & 4 & 5 \\
\hline
\end{tabular}

